NASZA DERMATOLOGIA Online OUR DERMATOLOGY Online Nil

Competing Interests: None declared

\section{THE PROBLEM OF SYNONYMS}

\author{
Daifullah Al Aboud
}

Dermatology Department, Taif University, Taif, Saudi Arabia

Corresponding author: Dr. Daifullah Al Aboud

dalaboud@hotmail.com
I read with great interest the recent paper by $\mathrm{Al}$ Aboud [1], about the problem of synonyms in medical literature.

I concur with the author that this problem needs to be addressed by the concerned people, now before later.

Dr Al Aboud elaborated on the synonyms of multiple symmetric lipomatosis. However, in medicine, one can find multiple synonyms for dozen, if not hundreds of diseases.

In this letter, I am giving another example with Menkes disease, for which there are eight names in medical literature. Menkes disease is a very rare $\mathrm{X}$-chromosome disorder affecting copper metabolism [2,3]. Menkes et al. in 1962 [4], first described the disease in a family of English-Irish descent living in New York, who presented by early retardation in growth, peculiar hair, and focal cerebral and cerebellar degeneration [4].

The disease leads to psychomotor retardation, pili torti, pallor, seizures and death in infancy or early childhood. There is marked skin pallor and laxity resembling cutis laxa. The responsible gene has been identified as a coppertransporting ATPase. Disruption of copper-dependent oxidation of tyrosine to dihydroxyphenylalanine (DOPA) results in diminished tyrosinase activity which manifests clinically as diffuse cutaneous hypopigmentation [3].

The initial diagnosis of Menkes disease is suggested by clinical features. Serum copper and ceruloplasmin levels are low, but interpretation may be difficult in the first Months of life. Definitive diagnosis can be made by demonstration of abnormal intracellular accumulation of copper in cultured fibroblasts. Examination for hair shaft Abnormalities can usually be accomplished with light microscopy using phase contrast optics. Unfortunately, the prognosis for MKHS is still grim, with most patients dying by the age of 3-4 years. Administrations of oral and parenteral copper have not proven successful [2].

The disease is named after John Hans Menkes [5-7] (19282008) (Fig. 1). Menkes, was born in Vienna. In 1939, following the German annexation of Austria, the family fled Austria and immigrated to the USA via Ireland. Menkes was then eleven years old. Menkes, son and grandson of physicians, followed the family tradition and studied medicine, despite his wish to become a journalist [6].

Menkes became head of pediatric neurology at the Johns Hopkins Hospital and later at the University of California, Los Angele (UCLA) [6].

In 1974 he entered private practice but returned to academic medicine in 1984 as professor of neurology and pediatrics at UCLA [6].

In 1997 he was named director of pediatric neurology at the Los Angeles' Cedars-Sinai Medical Center.

He identified Menkes disease, maple syrup urine disease and other congenital disorders of the neural system and established the pediatric neurology program at UCLA5. Menkes has published numerous papers and a textbook of child neurology. He has also written several novels. He has received some literary prizes [6].

He was named one of the „Best Doctors in America” in 1992, 1994 and 1996 and was among the „American Men and Women of Science" in 1996 [6].

He died Nov. 22 at Cedars-Sinai Medical Center in Los Angeles of complications of chemotherapy for colonic carcinoma. He was 79 [5].

Over the years, there was a debate about the best name for Menkes disease. Some authors think that, "Kinky hair disease" proved a designation useful in detection of new cases, since the hair change is an easily remembered feature by which physicians can be alerted to the condition. While others, pointed out that the hair may not be abnormal, and that serum copper determination is a simple and reliable diagnostic test, therefore they suggested "congenital hypocupraemia", as a preferred designation [8].

Table I, illustrate the discrepancy in the number of citations obtained using the synonyms for this disease. Although , this medical condition fits well into a ,syndrome”, „Menkes disease", seems to be the most currently and frequently, used for this condition.

Finally, I agree with Dr Al Aboud, about the importance of having a uniform and standard terminology in medical field, although this goal is difficult to achieve [1]. 


\begin{tabular}{|c|l|}
\hline The names & $\begin{array}{l}\text { Number of citations in } \\
\text { PubMed using the term } \\
\text { as a search words }\end{array}$ \\
\hline Copper transport disease & 1675 \\
\hline Kinky-hair syndrome & 912 \\
\hline Menkes disease & 1301 \\
\hline Menkes' disease & 927 \\
\hline Menkes syndrome & 1030 \\
\hline $\begin{array}{c}\text { Menkes' kinky-hair syndrome } \\
\text { (MKHS) }\end{array}$ & 890 \\
\hline Steely-hair syndrome & 903 \\
\hline Trichopoliodystrophy & 895 \\
Table I. The different numbers of citations obtained from \\
searching the PubMed with synonyms of Menkes disease, as \\
of 1 July 2012
\end{tabular}

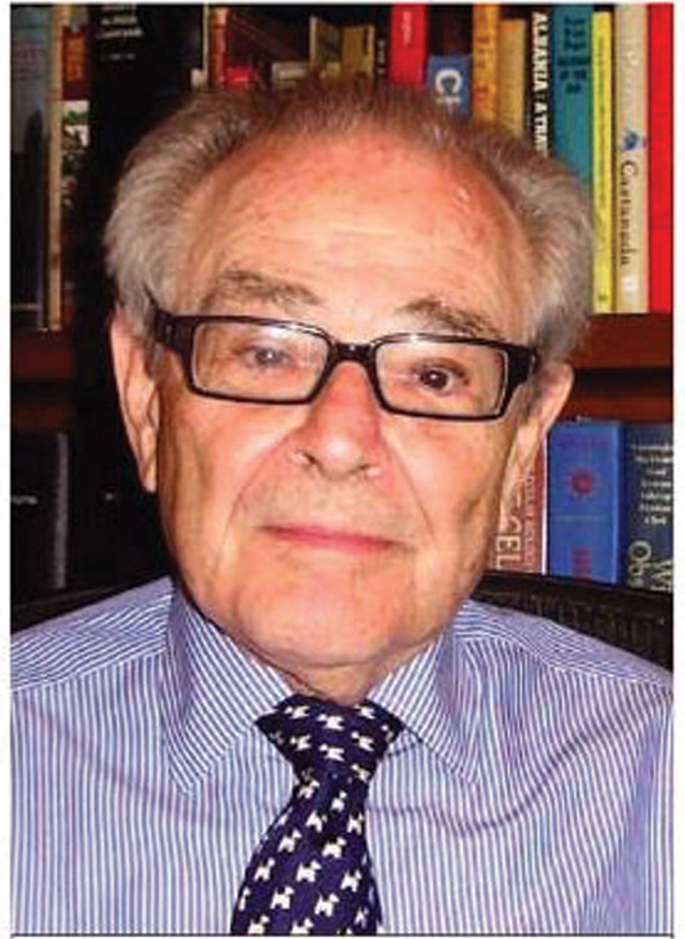

Figure 1. John Hans Menkes (1928-2008). Reprinted with permission from Neurology Today, an official publication of the American Academy of Neurology

\section{REFERENCES}

1. Al Aboud K: The problem of synonyms; multiple symmetric lipomatosis, as an example. Our Dermatol Online. 2012;3237-8.

2. Peterson J, Drolet BA, Esterly NB: What syndrome is this? Menkes' kinky-hair syndrome. Pediatr Dermatol. 1998;15:137-9. 3.Fistarol SK, Itin PH: Disorders of pigmentation. J Dtsch Dermatol Ges. 2010;8:187-201.

4. Menkes JH, Atler M, Steigleder GK, Weakley DR, SungJH: A sex-linked recessive disorder with retardation of growth, peculiar hair, and focal cerebral and cerebellardegeneration. Pediatrics. 1962;29:764-79.
5. Maugh II TH: Obituary; John H. Menkes dies at 79; doctor established UCLA's pediatric neurology program.Los Angeles Times; Available online; http://www.latimes.com/news/science/lame-menkes29-2008nov29,0,7736712.story

6. John Hans Menkes: A page in the internet.Whonamed it. (C) 1994 - 2012 Ole Daniel Enersen. Available online at; http://www. whonamedit.com/doctor.cfm/3333.html

7.Sarnat HB: In memoriam:John Hans Menkes. Available online at; http://www.childneurologysociety.org/assets/files/menkes_obit. pdf

8. Osaka K, Sato N, Matsumoto S, Ogino H, Kodama S: Congenital hypocupraemia syndrome with and without steely hair: report of two Japanese infants. Dev Med Child Neurol. 1977;19:62-8. 